\title{
Neotectonic aspects of the northern margin of the Adana-Cilicia submarine basin, NE Mediterranean
}

\author{
E Ozel*, A Ulug and B Pekcetinoz \\ Institute of Marine Sciences and Technology, Dokuz Eylul University, Inciralti 35340 Izmir, Turkey. \\ *e-mail: erdeniz.ozel@deu.edu.tr
}

\begin{abstract}
The sedimentary basins that dominate the north-eastern Mediterranean (Adana-Cilicia basins in the west and Iskenderun basin in the east) are located on the flanks of a partly submerged positive structure (a part of the Africa-Eurasia convergence zone) along which strike-slip faults are evident. This study summarizes the findings of two seismic surveys carried out in the AlanyaMersin offshore region. Some $850 \mathrm{~km}$ of geophysical survey lines were compiled on these cruises. Based on the results determined from these surveys, the north and central part of Adana-Cilicia basin can be subdivided into eastern, central and western structural sub-basins separated by the Ecemiş fault complex in the east and the Anamur-Kormakiti structural high in the west at the same time. Results of this study also indicate that Ecemiş and Anamur-Kormakiti faults are active. Late Miocene regional compression was responsible for the compartmentation of this complex into the present arrangement and has initiated the rotational regime which has governed subsequent tectonic developments, notably the extensional behaviour of the NE-SW trending Ecemiş and Anamur-Kormakiti faults and the transpressive behaviour of the NNE-SSW trending border fault complex.
\end{abstract}

\section{Introduction}

The Cyprus Arc comprises several distinct morphological domains: The Florence Rise and part of the Anaximander Mountains to the west, the island of Cyprus and the Kyrenia Rise in the east. From the Pliocene to Recent, it has been mainly viewed as a convergence zone where the African plate is consumed beneath the Anatolian microplate (Robertson 1998a). The Cyprus Arc segment is considered to be almost blocked now by the collision of Erastothenes Seamount there (e.g., Robertson 1998b; Glover and Robertson 1998; Veen et al 2004). The eastern part of the Cyprus Arc is a typical transpressional feature (Ben-Avraham et al 1995; Vidal et al 2000), where the subduction stopped before the Messinian period. The structural settings are different on the two sides of the Kahramanmaras triple junction which is the junction of the Dead Sea Transform Fault, the Kyrenian-Misis Zone and the East Anatolian Fault (figure 1). On the east, structures controlled by strike-slip and compression coexist, whereas on the west compression is less conspicuous. Here, deep basins which are the Cenozoic depocentres of the Adana-Cilicia and Iskenderun Basin complexes, Antalya and Latakia Basins separated by a partly submerged ridge, are prominent (Kempler and Garfunkel 1994). Kempler and Garfunkel (1994) have interpreted this ridge (the Kyrena-Misis Thrust) as a large flower structure which extends from southeastern Turkey to Cyprus. The Adana-Cilicia and the IskenderunLatakia Basins on its flanks were interpreted as being due to extension (Aksu et al 1992, 2005; Işler et al 2005).

The Misis-Kyrenia fault zone (figure 1) links the Misis Mountains of southern Turkey and the Kyrenia Range of northern Cyprus (Anastakis and Kelling 1991; Aksu et al 1992, 2005; Issler et al 2005).

Keywords. Cilicia basin; seismic data; active faults; Ecemiş fault; NE Mediterranean. 


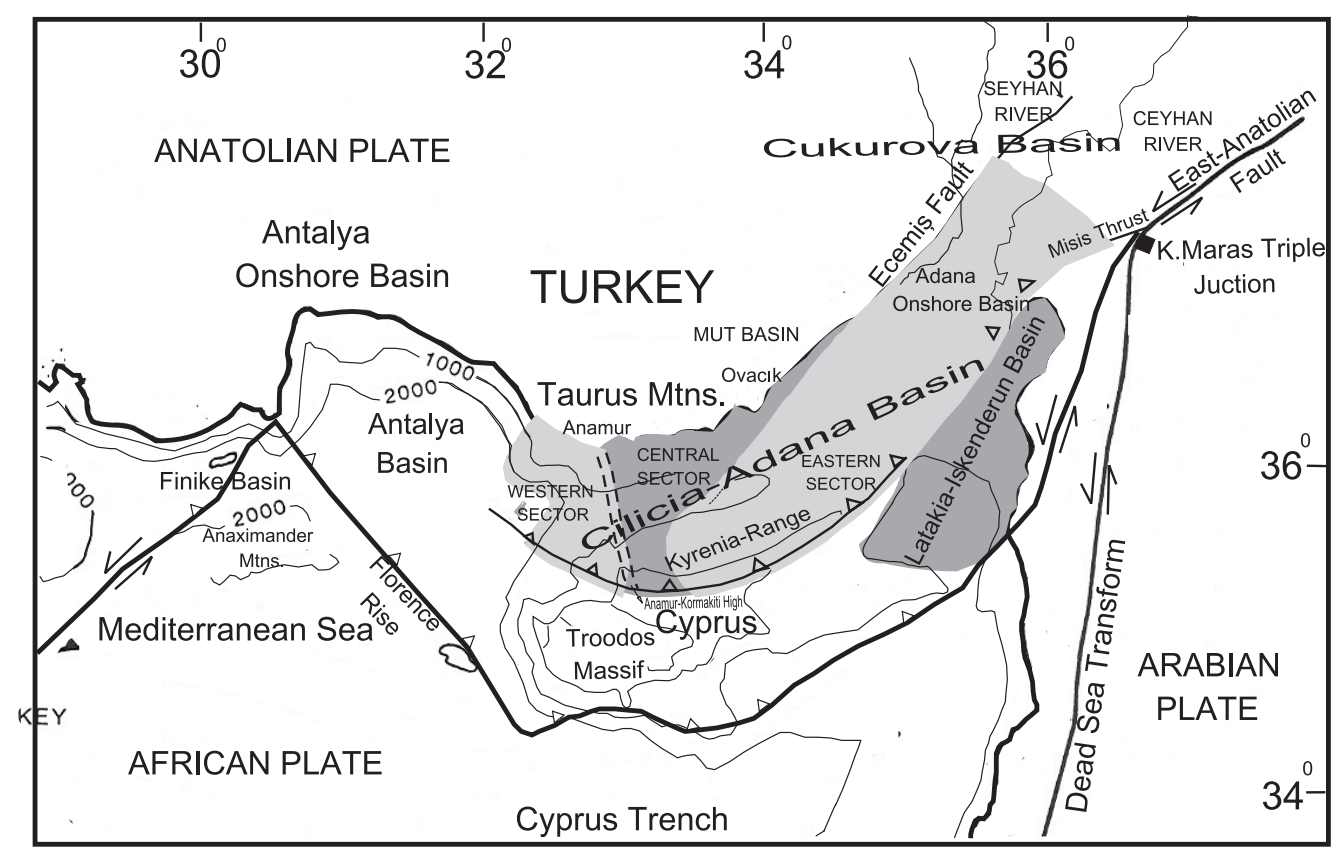

Figure 1. General geotectonic setting of the NE Mediterranean, showing location of the Adana-Cilicia trough with respect to adjacent Neogene and neotectonic basins and structural features (modified from Şengör and Yılmaz 1981; Hancock and Barka 1980 and Dewey et al 1986; Veen et al 2004; Aksu et al 2005).

The Adana-Cilicia Basin which is located between the early Cenozoic Tauride belt and the narrow late Cenozoic Misis-Kyenia (Cyprus) lineament, is a Neogene extensional structure formed within the broadly convergent setting of the northeast Mediterranean. It was influenced by the Arabian-Eurasian collision (to the east), HellenicCyprian subduction (to the west and south) caused by the northward movement of the African plate and westward tectonic 'escape' of the Anatolian microplate along the $\mathrm{N}$ and $\mathrm{E}$ Anatolian Faults (Şengör et al 1985; Dewey et al 1986; Bozkurt 2001).

The Adana-Cilicia Basin is actually a portion of the former, much larger, Çukurova Basin complex, which also includes the Iskenderun-Latakia trough and the intervening Misis-Kyrenia structural high (figure 1), which demarcates the southern boundary of the Adana-Cilicia structural depression. The western boundary of Çukurova basin is represented by a steep, dissected internal slope (underlined by the Anamur-Kormakiti basement high), separating the Cilicia trough from the deeper Antalya Basin. Morphologically defined by the boundaries specified above, the Cilicia Basin has a submerged area extent of some $15,000 \mathrm{~km}^{2}$. It is characterised by relatively narrow shelves to the north and south, with the wide Seyhan delta-front platform to the east. The slope sectors (commencing at around $200 \mathrm{~m}$ water depth) are comparatively wide and constitute around $20 \%$ of the total area.
The Turkish slope appears to be significantly more dissected and transected by canyons and gullies, compared to the relatively smoother slope of northern Cyprus (Evans et al 1978; Hooker 1981). The basin floor lies generally around $800-1000 \mathrm{~m}$ depth. The offshore Cilicia Basin continues northeastwards under the plains of the Seyhan Delta which represents the youngest part of the fill of the Adana Basin, the subsidence history of which appears to have been initiated in the late Oligocene or earliest Miocene (Kelling et al 1987). At present, Adana Basin is separated from the broadly coeval Mut Basin to the west (figure 1) by the important Ecemiş Fault lineament.

The nature and origin of the Adana-Cilicia Basin has evoked some recent debate, mostly based upon the assessment of regional seismicity or plate kinematic consideration. Recent geodetic measurements in the region (e.g., Le Pichon et al 1995; McClusky et al 2000; Kahle et al 2000) indicate (a) that there is a relatively small convergence rate between Anatolia and Africa along the Cyprus Arc (e.g., rates of about $7 \mathrm{~mm} / \mathrm{yr}$ according to McClusky et al 2000), (b) that the plate interaction occurring there is more oblique ENE-WSW than normal to the boundary and (c) that the pole of rotation describing this interaction is relatively near (possibly as close as $600 \mathrm{~km}$ to the south), in keeping with the apparent deformation rates. This confirms marine observation (Woodside et al 2002) from the eastern Cyprus Arc which indicates 


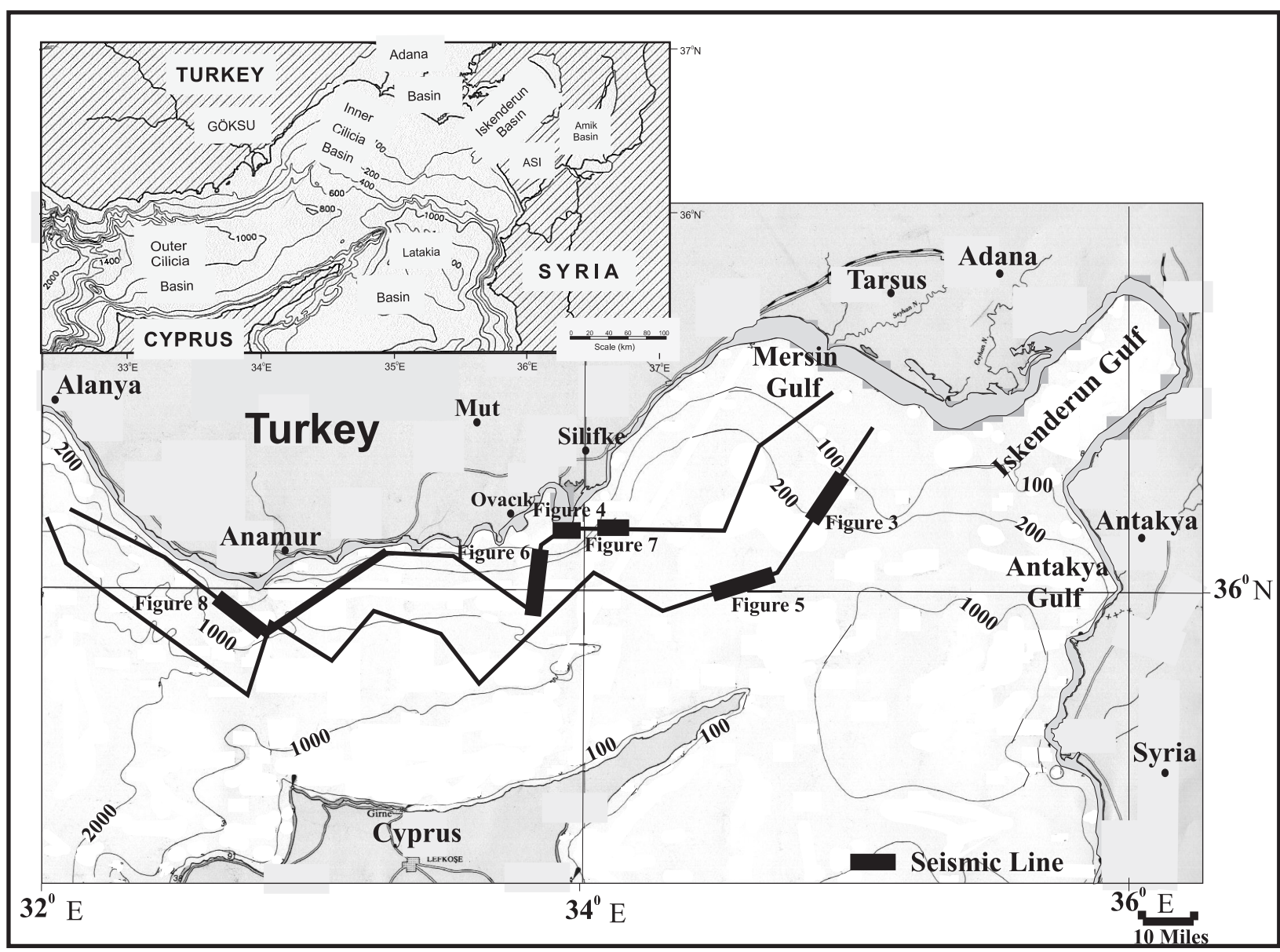

Figure 2. The figure above is general bathymetry of the study area (Aksu et al 2005). In the figure below, track-lines for seismic reflection profiling programmes on 1988 and 1989 cruises of R/V K. Piri Reis are shown.

broad, relatively undeformed (Vidal et al 2000) zones separated by narrow corridors of transpressive shearing (Ben Avraham et al 1995). AdanaCilicia Basin has been described as a marginal trough associated with plate collision (Biju-Duval and Montadert 1977; Vidal et al 2000), as part of forearc-basin complex (Jackson and McKenzie 1984). This basin is a possible major pull-apart associated with an extension of the East Anatolian Transform (Dewey et al 1986) or as an incongrous feature in the region, generated after formation of the Kahramanmaras Triple junction and related to westwards tectonic escape of Anatolia (Sengor et al 1985). Onshore studies of the Misis Complex (Kelling et al 1987; Gokcen et al 1988) have suggested a complex geotectonic evolution for the Adana Basin, involving an early phase of peripheral foreland basin development succeeded in the late Miocene/early Pliocene by a transtensional regime generated during the westward tectonic escape of Anatolia and following inception of the Kahramanmaraş triple junction (Sengor et al 1985).

However, the role of the offshore AdanaCilicia Basin in these geotectonic scenarios remains poorly defined and therefore a marine geological research programme has been designed to address this question, and specifically, to investigate the tectono-stratigraphic framework and neotectonic processes which have governed the evolution of the Adana-Cilicia Basin, especially the northern and western margins of that trough. The data reported here are derived from the two cruises undertaken by the $\mathrm{R} / \mathrm{V} \mathrm{K}$. Piri Reis belonging to the Institute of Marine Science and Technology of Dokuz Eylül University, Izmir, in 1988 and 1989. Some $850 \mathrm{~km}$ of geophysical survey lines were compiled on these cruises (figure 2).

Position locations were achieved using satellite navigation. Single channel seismic reflection profiling was undertaken with the aid of an EEG PAR-600 airgun (40 cubic inch) with a pulse-rate of 2 seconds, towed at a depth of $2-3 \mathrm{~m}$. Signals were received with a Benthos 460 streamer, which is single channel with 6 parallel hydrophone and $10 \mathrm{~m}$ length, and processed through a Khron-Hite 3700 band-pass filter into an EPC Graphic/tape recorder. 

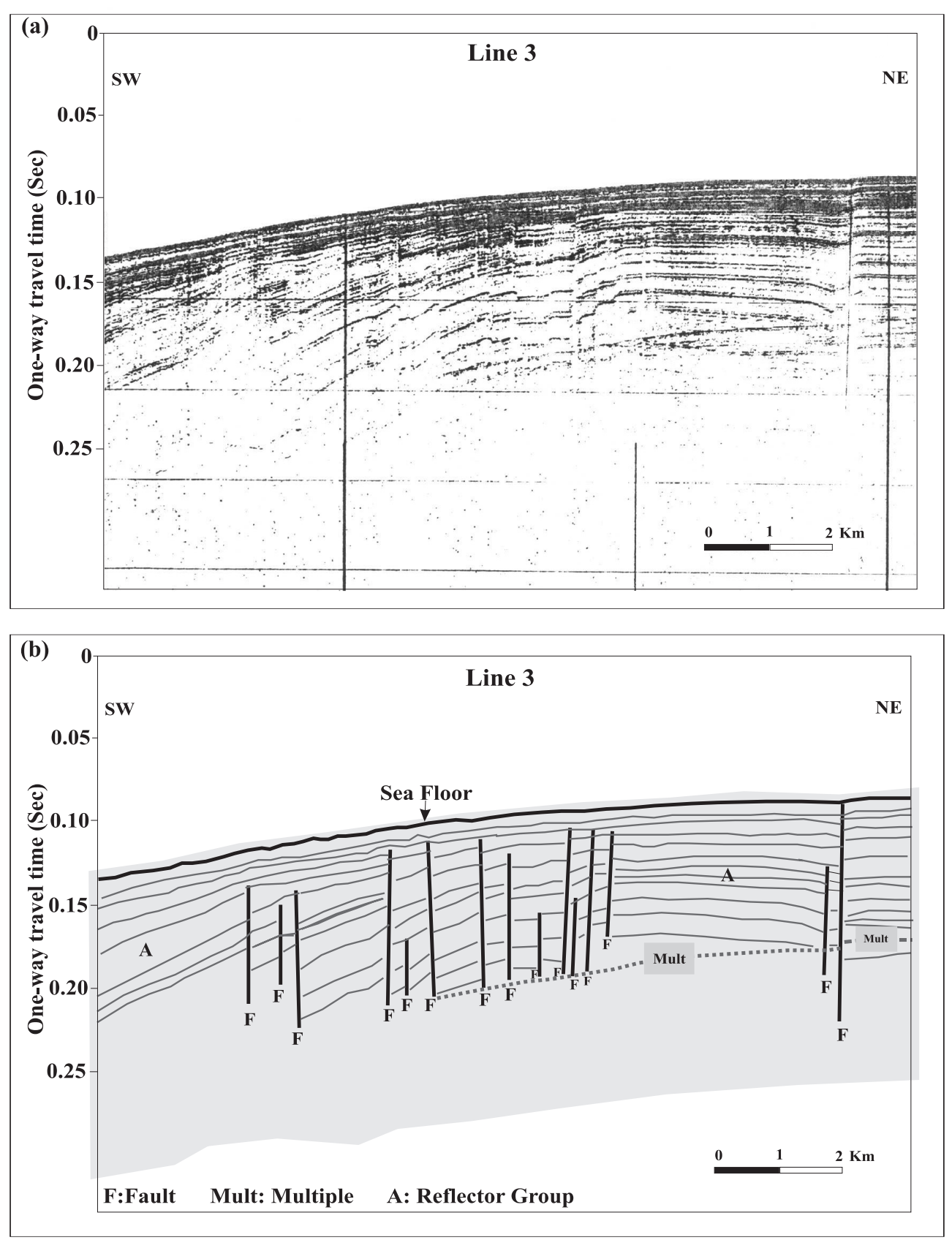

Figure 3. Line number 3 single-channel seismic profile (a) and interpreted line drawing (b) through the distal pro-delta region of the Seyhan Delta (see figure 2 for location), showing the upper part of the thick Plio-Quaternary sequence developed in this region. Note the array of faults and general progradational (divergent) character of Plio-Quaternary reflectors here.

\section{Seismic stratigraphy}

Within the relatively shallow-penetration profiles obtained in this study, three main reflector groups can be distinguished on the basis of relative depth, the nature and attitude of mutual contacts. These profiles indicate one-way travel time.

The shallowest reflector group (A) is characterised by close-spaced, sub-parallel reflectors, essentially concordant with the seafloor but locally (especially in shelf and upper slope profiles) displaying internally divergent reflector geometry of progradational type (figure 3). Discrete slumpmasses up to $50 \mathrm{~ms}(=80 \mathrm{~m})$ thick occur in this zone at several places near the base of the continental slope. The meniscoid pattern of near-seafloor reflectors described by Hooker (1981) as 'giant ripples' is patchily developed within the reflector group A on the Turkish shelf and uppermost slope south of Anamur. The thickness of the reflector group is highly variable. The average thickness 

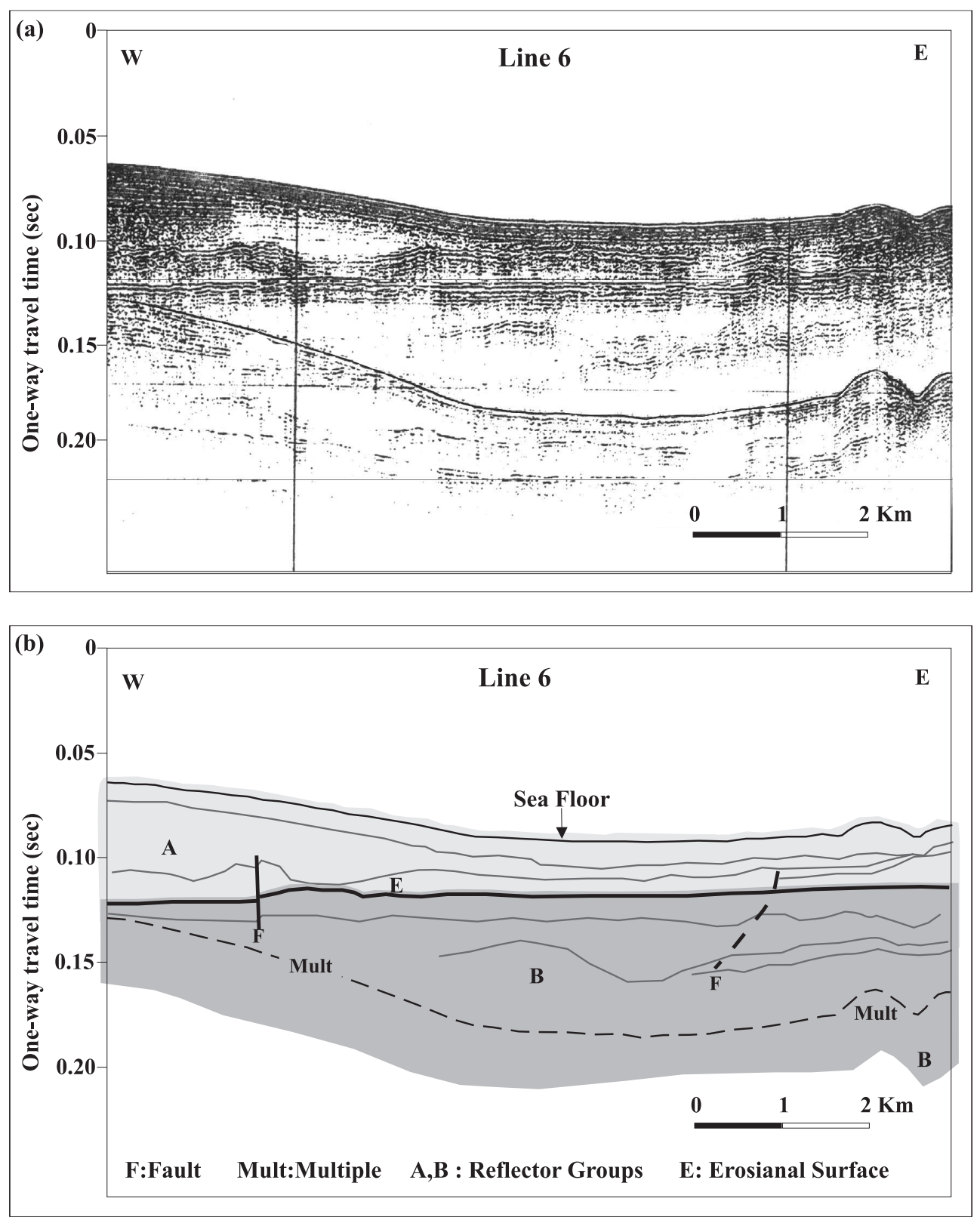

Figure 4. Line number 6 single-channel seismic profile across outer shelf, south of Silifke (see figure 2 for location), illustrating the condensed sedimentary succession seen below much of the Turkish shelf. E - erosional surface, probably separating unit A from unit B.

observed is around $80 \mathrm{~ms}$ on shelf profiles. The thickness diminishes in the morphologically rough inner shelf, immediately south of Silifke (figure 4). Unusually thick developments of group A occur: on the shelf and lower slope south of Anamur (northeast flank of the Anamur-Kormakiti structural high), the slope south of Ovacik, and the prodelta slope of the Seyhan Delta, south of Mersin (figures 3 and 4).

Reflector group B also comprises close-spaced, sub-parallel reflectors, sometimes disposed in alternating bundles of prominent and less distinct reflectors, a few tens of milliseconds thick.
These reflectors are everywhere warped or folded or affected by faulting, including faults and more brittle, through-going fractures (figures $4-7$ ). The upper surfaces of this reflector group is usually in discordant contact with the base of group A, although a near-gradational passage between the two groups is observed in some slope-base and basin-floor profiles from the easternmost Antalya Basin, the deep Cilicia Basin south of Ovacık (figure 6) and from the diapiric zone in front of the Seyhan Delta (figure 5).

The geometry and dimensions of the folds affecting group B vary greatly, from gentle warps with 


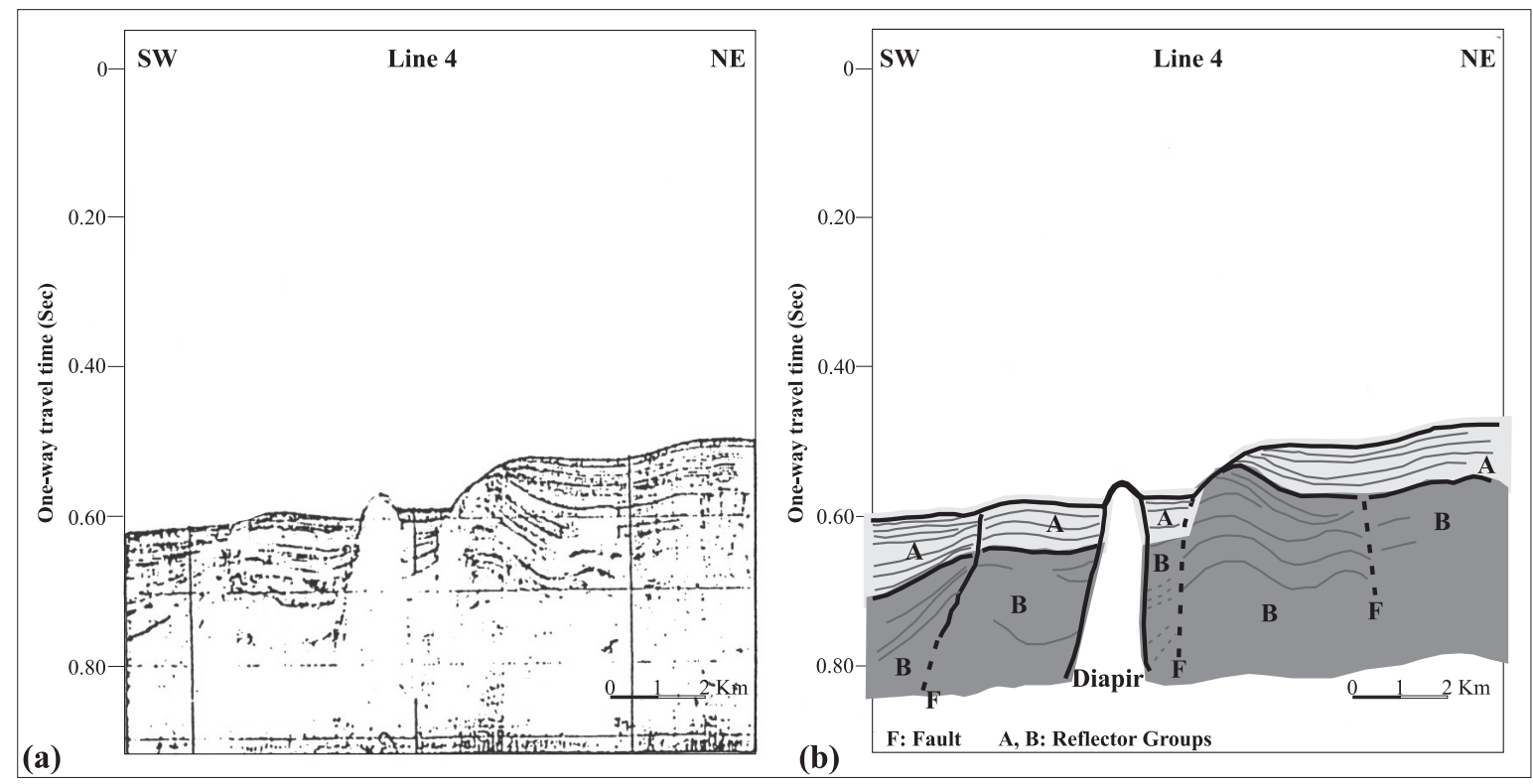

Figure 5. Single-channel seismic profile line number (4) across base of Seyhan Delta (see figure 2 for location), showing halokinetic deformation of upper Plio-Quaternary, including an emergent diapir and some faults.

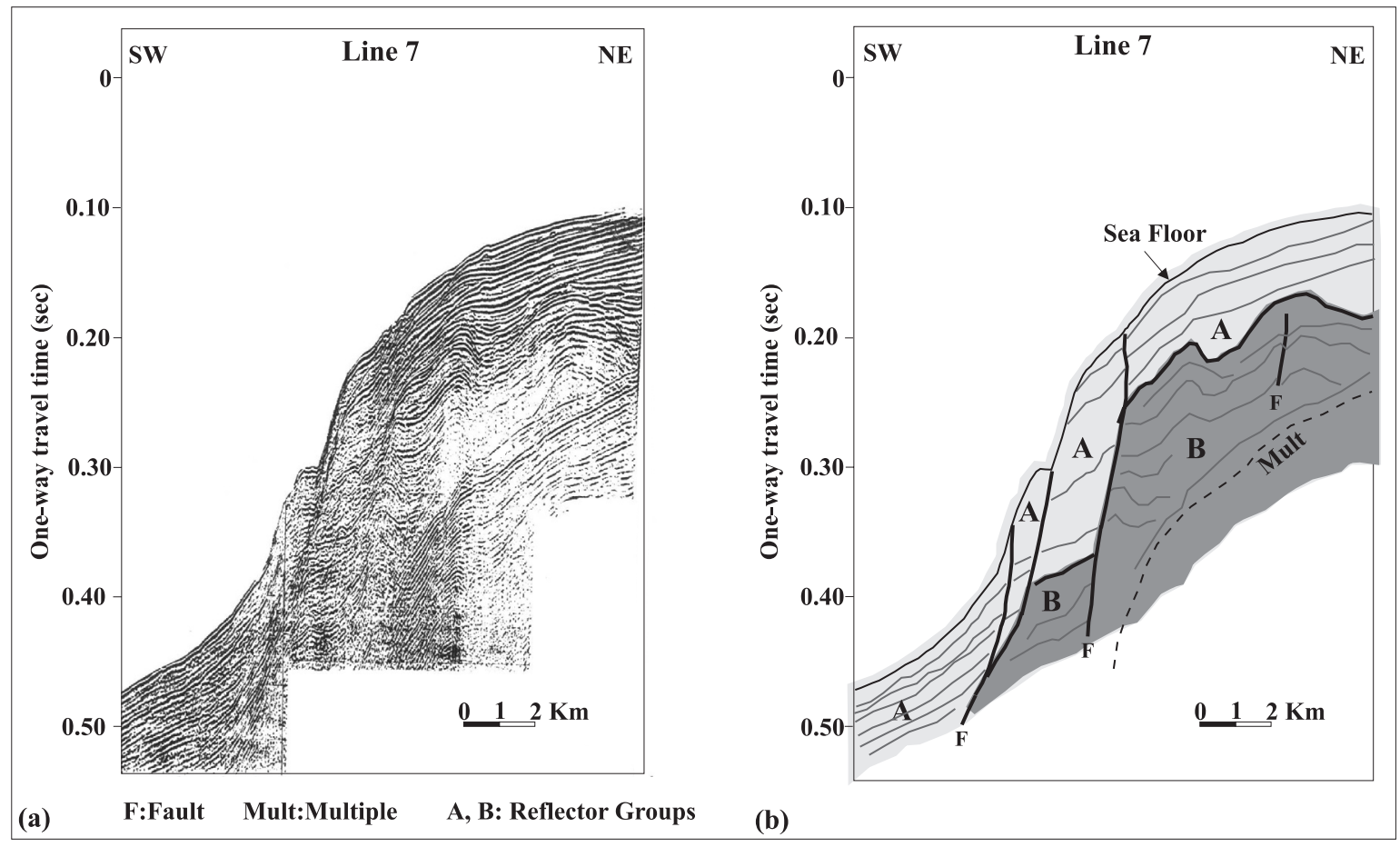

Figure 6. Line number 7 single-channel seismic profile across upper Turkish slope south of Ovacık (see figure 2 for location). Note the several faults affecting the entire Plio-Quaternary $(\mathrm{P}-\mathrm{Q})$; tight folds locally developed in the older $\mathrm{P}-\mathrm{Q}$ sequence; the discordant truncation of most of these folds against the substantial thickness of the post-Messinian succession here.

wavelengths in excess of $10 \mathrm{~km}$ and amplitudes of $60-70 \mathrm{~ms}(=80-90 \mathrm{~m})$ to relatively small, tight plications, a few hundreds of metres in wavelength and with amplitudes of average $12.5 \mathrm{~ms}(\sim 20 \mathrm{~m})$.
These folds appear to be associated mainly with the Seyhan diapir field (figure 5). Asymmetry of the major folds is not conspicuous but, where detectable, limbs of the larger folds generally face 


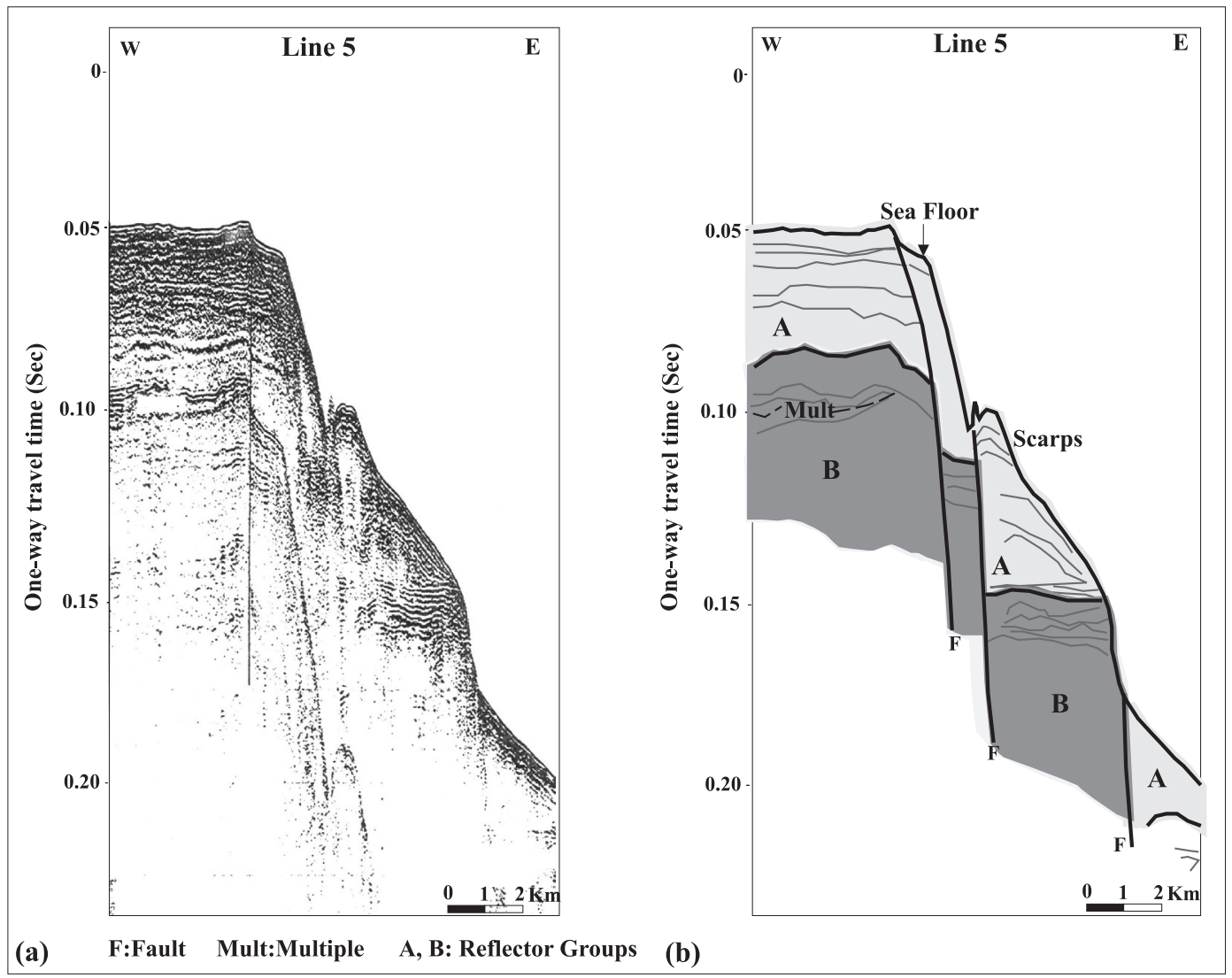

Figure 7. Line number 5 single-channel seismic profile across major fault-complex (extension of Ecemiş lineament) SE of Silifke. Downslope thickening of the Plio-Quaternary $(\mathrm{P}-\mathrm{Q})$ and Quaternary $(\mathrm{Q})$ is also evident.

to the north or northeast, and thus contrast with the south-facing comparable structures reported by Evans et al (1978) from the eastern part of the basin.

Reflector group C cannot be observed very clearly because of the insufficient acoustic energy of the seismic system performed for this study (figure 8). From this observation, the boundary between Group B and Group C is displaced by normal and reverse or thrust faults. In the deeper sectors of the western part of the study area (Antalya Basin and Anamur region) the geometry of the folded boundary is broadly concordant with the folds within reflector group B in the same region. However, further east of the shelf, slope profiles reveal some discordance between the deformation features observed in the two groups.

\subsection{Stratigraphic correlation}

The reflector group A (plio-Quaterner sediments) is discordant contact with the underlying group B. Both onshore and offshore boreholes in the vicinity of the Ceyhan and Goksu deltas have yielded Quaternary succession (Aksu et al 1992, 2005). Therefore, B reflector group must extend into the Pliocene age. The Deep Sea Drilling Project (DSDP) and onshore exploration wells have determined that the age of the reflector correlatable to the top of unit $\mathrm{C}$ is of Messinian age (e.g., Hsü et al 1973; Ryan and Cita 1978; Işler et al 2005) and has demonstrated that in most of the Mediterranean region this reflector marks the top of a thick sequence. Group B in the Cilicia Basin is similar to the seismic signature of sequences encountered above the Messinian reflector in adjacent areas of the eastern Mediterranean, and generally ascribed to the main part of the Pliocene succession (Yalçın and Görür 1984).

Strata attributed to the Pliocene attain thicknesses of as much as $1600 \mathrm{~m}$ in oil exploration boreholes from the front of the Seyhan Delta (Rigassi 1971; Evans et al 1978), comparable to the $1070 \mathrm{~m}$ maximum thickness of Group B encountered in the same area during the present study.

As indicated above, the Messinian reflector indicates the upper limit of group $\mathrm{C}$ sequence. The group $\mathrm{C}$ sequence is represented by discontinuous reflector and scattered echoes (figure 8). The discontinuous reflector and scattered echoes may be because of the lower resolution of signal at greater penetration depth. 


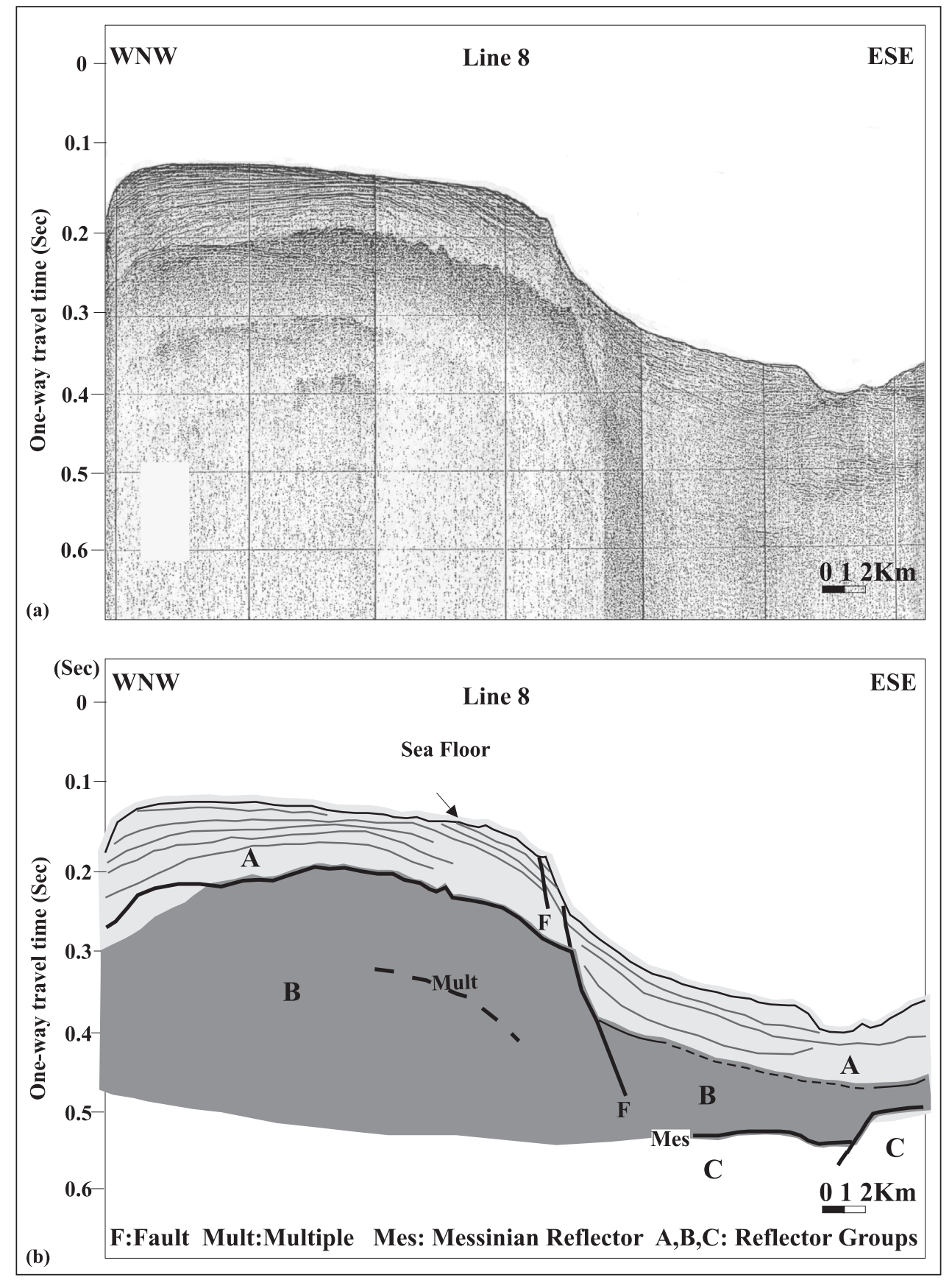

Figure 8. Line number 8 single-channel seismic profile across the northern end of the Anamur-Kormakiti buried structural high (see figure 2 for location). The Mes reflector (Mes reflector is the Messinian reflector and the top of unit $\mathrm{C}$ ) at the southeast end of this profile can be traced below the floor of the adjacent Antalya Basin, but appears to be imbricated and stacked further east.

\subsection{Structural aspects}

The northern and central parts of the AdanaCilicia Basin can be subdivided into three main regions, on the basis of shallow and intermediate structural features, which differ from east to west. These can be termed as the western, central and the eastern subregions. A major fault complex attributed to an offshore extension of the Ecemis Fault separates the eastern portion from the central, while the Anamur-Kormakiti structural high demarcates the western portion (figures 1 and 9).

\subsubsection{Eastern sector}

The eastern sector lies between the Misis-Kyrenia system and the Ecemiş Fault. Aksu et al (1992) described the Inner Cilicia Basin as the E-W trending structure that comprises of a complex array of 


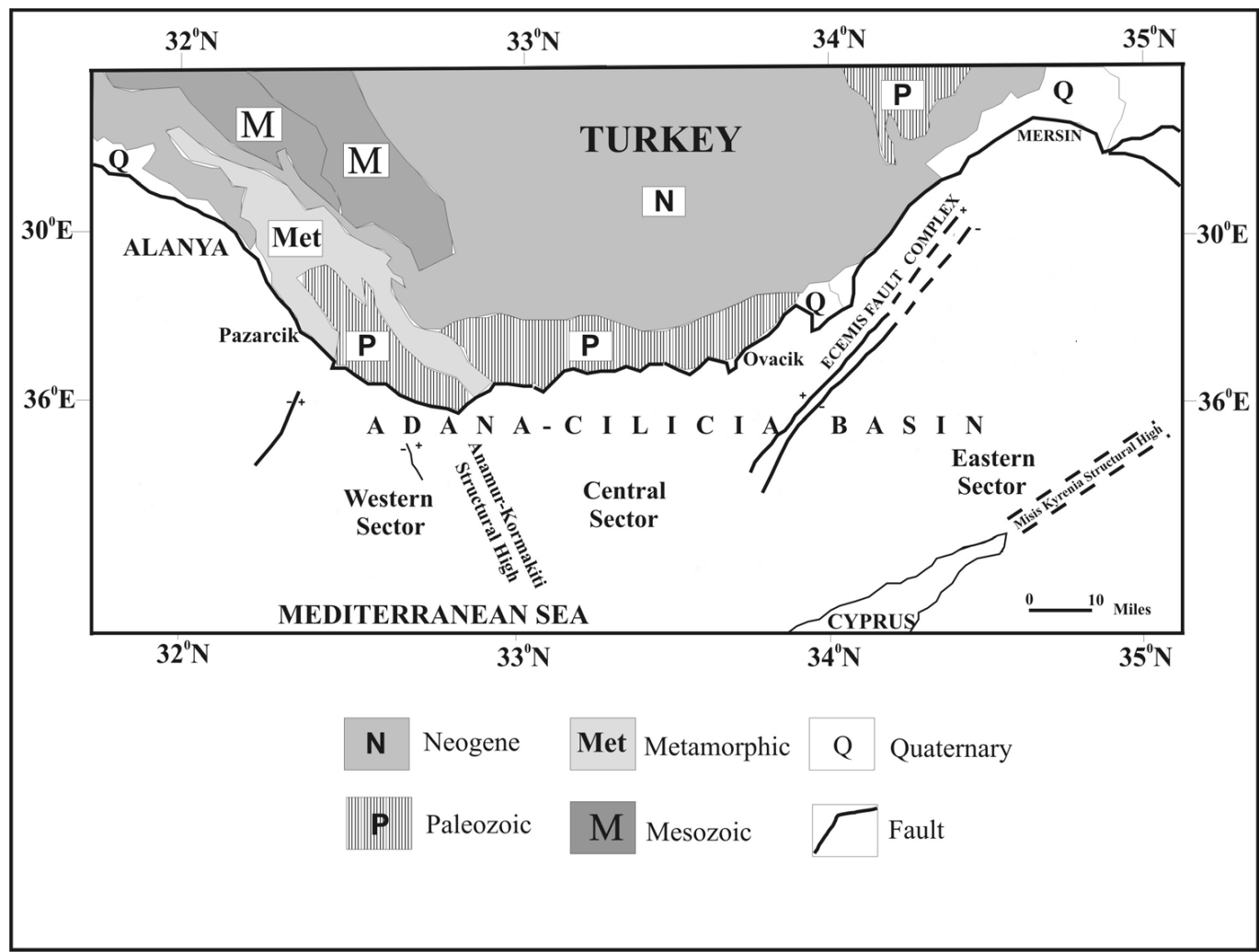

Figure 9. Map of geological and structural study area and adjacent areas. Sub-basins of Adana-Cilicia Basin. The general geology of the adjacent part of Turkey is also indicated (compiled from Gokcen et al 1988).

north- and south-dipping synthetic and antithetic listric normal faults where the detachment surface coincides with the base of the Messinian salt. They interpreted that the deeper outer Cilicia Basin is mainly controlled by salt diapirism, drawing from the Messinian evaporate sequence which was estimated to be at a thickness of $500 \mathrm{~m}$ (Bridge et al 2005).

This is characterised by:

- Deltaic sediments. This sector is described by a prograding wedge of deltaic sediments of the Seyhan river. These deltaic sediments can be observed over $100 \mathrm{~ms}$ in seismic lines 4 and 6 . In this sector, a predominantly transparent subunit represents with weak and discontinuous parallel reflections (figure 5). This subunit is correlated to the early Pliocene Formation (Aksu et al 2005). The northern slope of the Cilicia Basin is mantled by Plio-Quaternary sediments resting upon a Messinian horizon. However, the Plio-Quaternary cover is thin to absent on the Turkish shelf.

- Prominent Diapirs and growth faults. This sector became emergent during the Messinian salinity crisis, and up to $1000 \mathrm{~m}$ of evaporates were deposited (Aksu et al 2005). Also in the eastern sector, Messinian displays erosional character and is probably represented by shallow marine to terrestrial clastic facies. The folding and faulting (growth faults) in this sector are possibly related to the salt movement caused by loading by Seyhan sediments (figure 5).

\subsubsection{Central sector}

This sector lies between the marine extension of the Ecemis fault complex and the Anamur-Kormakiti buried structural high. The Messinian horizon can be traced throughout this region. In the Turkish shelf area, the thickness contours for the PlioQuaternary sequence are generally E-W trending with only a thin development beneath, but rapidly thickening down slope and accompanied by large slump masses both at the present sea floor and buried in the older part of the sequence.

The fracture system in the eastern part of central sector is observed on the seismic sections (figures 6 and 7). The location and clear tectonic importance of the fracture system strongly suggests that it represents an offshore extension of the well known Ecemis Fault complex, which marks the present western limit of the onshore Adana Basin. This fault is considered to have been active since Palaeogene times (Yetiş 1984). However, the location and behaviour of the southwestern extension of this lineament is not very obvious (Demirtasl and Genc 1986; Akay and Uysal 1988). 


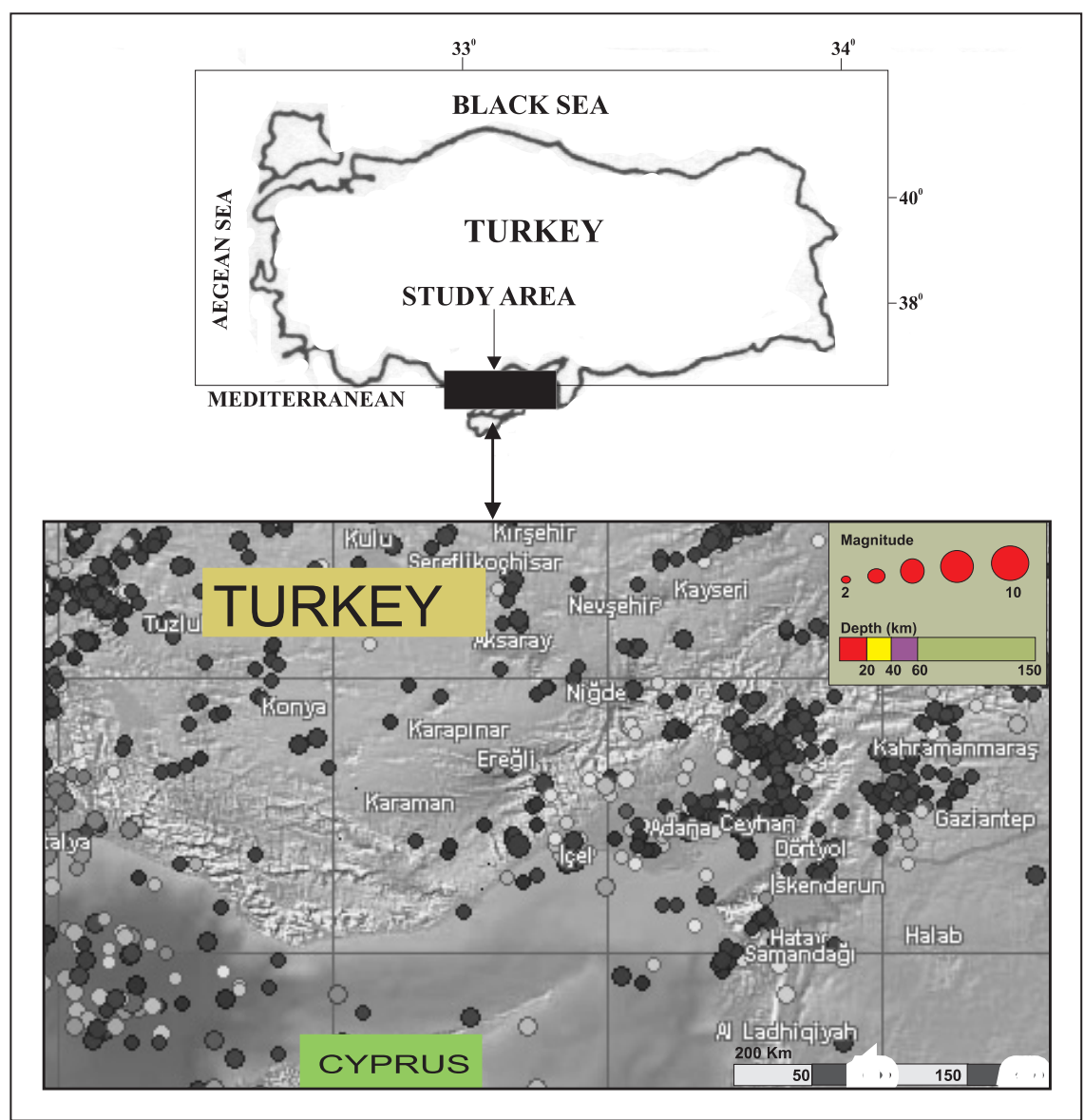

Figure 10. Distribution of epicentre locations recorded during the period 1990-2006 in the vicinity of the Cilicia Basin $(M \geq 3)$ (data obtained by Yakup Gezdirici, earthquake monitor-http://www.gezdirici.net/eqmon).

Regional seismic activity (figure 10) indicates that the Ecemis lineament extends as a presently active seismo-tectonic feature in the area around Mersin and in the offshore area to the southeast of Silifke (Doyuran et al 1989). The major submarine fracture system identified in the present study is plausibly regarded as an offshore extension of the Ecemiş lineament. Its recent history confirms the continuing tectonic activity of this feature, at least in the southeastern portion (see figures 6 and 7 ).

\subsubsection{Western sector}

This comprises the northeastern portion of the Antalya Basin, including the intrabasinal slope connecting with the Cilicia Basin, which is underlined by the roughly $\mathrm{N}-\mathrm{S}$ trending AnamurKormakiti basement high. This feature is buried beneath a significant thickness of $\mathrm{P}-\mathrm{Q}$ sediments (it can be observed up to $180 \mathrm{~m}$ in seismic section in figure 8).

However, the overlying sediments display signs of folding in the area immediately east of the Anamur-Kormakiti high. Thus, the western boundary of the Cilicia Basin probably was related to Mio-Pliocene compression, which was subsequently blanketed by Plio-Quaternary sediments, and later deformed by re-activation of this feature. It is noteworthy that the older structures of the Anamur-Kormakiti high appear to be truncated by the important $\mathrm{E}-\mathrm{W}$ trending normal fault system, which at least locally affects the PlioQuaternary sequences along much of the Turkish slope of the Cilicia Basin. West of Anamur the thick Plio-Quaternary sediments underlying the strongly dissected slope have been affected by $\mathrm{N}-\mathrm{S}$ trending normal faults and display a block and graben morphology. According to Işler et al (2005), below the Antalya Basin the present-day structural framework of the Anamur-Kormakiti high is characterized by an imbricate fold-thrust system.

\section{Conclusion}

The Cyprus Arc comprises several distinct morphological domains: The Florence Rise and part of the Anaximander Mountains to the west, the island of Cyprus and the Kyrenia Rise in the east. From 
the Pliocene to Recent, it has been mainly viewed as a convergence zone where the African plate is consumed beneath the Anatolian microplate. The Adana-Cilicia Basin which is located between the early Cenozoic Tauride belt and the narrow late Cenozoic Misis-Kyrenia (Cyprus) lineament, is a Neogene extensional structure formed within the broadly convergent setting of the northeast Mediterranean.

From the one-way travel time seismic section, three main seismic sequences can be distinguished within the northern submerged margin of the Cilicia Basin. These are separated by regional discordances, and three main structural domains can be distinguished:

- the eastern sector corresponding to the offshore Adana Basin dominated by halokinetic and growth-fault tectonics resulting from interaction of Seyhan delta progradation with a Messinian depocentre characterised by neotectonic extension;

- the central sector demarcated to the east and north by major fault complexes, both of which appear to be still active. The eastern fault system appears to be an offshore extension of the Ecemiş lineament. The NE-SW trending northern fault complex is associated with locally more intense deformation of the Plio-Quaternary, suggesting a transpressive kinematic regime here;

- the western sector comprises the northeastern portion of the Antalya Basin and includes a prominent NS-oriented structural high (Anamur-Kormakiti high) with a thick cover of Plio-Quaternary sediments. Below the Turkish shelf and slope this high appears to be formed by extensional/transtensional faults of EarlyPliocene age (Işler et al 2005) and is truncated by the younger $\mathrm{E}-\mathrm{W}$ trending border faults. Further west, the basin floor and northern slopes of Antalya Basin reveal halokinetic deformation, apparently related to $\mathrm{N}-\mathrm{S}$ trending faults and local thrusts, indicating continued compressive deformation in this sector.

\section{Acknowledgements}

This study represents a contribution within the terms of a collaborative research agreement concluded between Dokuz Eylul University (Izmir, Turkey) and University of Keele (StaffsEngland). We are grateful to U K Natural Environment Research Council for partial funding, Prof. Dr. Gilbert Kelling and Prof. Dr. Mustafa Ergün. We gratefully acknowledge late Prof. Dr. Sungu Gokcen for this endeavour begun by them during 1988-89 and Prof. Dr. Nuran Gokcen.

\section{References}

Akay E and Uysal S 1988 Post-Eocene Tectonics of the Central Taurus; Maden Tetkik Arama Bülteni, Ankara 108 57-68 (in Turkish).

Aksu A E, Calon T J, Piper D J W, Turgut S and Izdar E 1992 Architecture of late Quaternary basins in northeastern Mediterranean; Tectonophys. 210 191-213.

Aksu A E, Calon T J, Hall J, Mansfield S and Yaşar D 2005 The Cilicia-Adana basin complex, Eastern Mediterranean: Neogene evolution of an active fore-arc basin in an obliquely convergent margin; Mar. Geol. 221 $121-159$

Anastakis G C and Kelling G 1991 Tectonic connection of the Hellenic and Cyprus arcs and related geotectonic elements; Mar. Geol. 97 261-277.

Ben-Avraham Z, Tibor G, Limonov A F, Leybov M B, Ivanov M K, Tokarev M Yu and Woodside J M 1995 Structure and tectonics of the eastern Cyprean Arc; Mar. Petrol. Geol. 12(3) 263-271.

Biju-Duval B and Montadert L 1977 Introduction to the structural history of Mediterranean Basins; International Symposium on the Structural History of the Mediterranean Basins, Split (Yugoslavia) Editors Technip, Paris, pp. 1-12.

Bozkurt E 2001 Neotectonics of Turkey - a synthesis; Geodinamica Acta 14 3-30.

Bridge C, Calon T J, Hall J and Aksu A E 2005 Salt tectonics in two convergent-margin basins of the Cyprus arc, Northeastern Mediterranean; Mar. Geol. 221 185-210. doi: 10.1016/j. margeo. 2005.03.008.

Demirtasl E and Genç M 1986 Final report of the tectonic investigation of the region between the Akkuyu site, Silifke-Mersin-Tarsus coastal area, Adana and İskenderun Basins, Ecemiş Fault Zone, Bolkar mountains, EreğliUlukışa Basin and eastern part of the Mut basin; Unpubl. Rept. Maden Tektik Arama, Geological Research Department, Ankara, 65pp.

Dewey J F, Hempton M R, Kidd W S F, Saroğlu F and Sengör A M C 1986 Shortening of continental lithosphere: the neotectonics of Anatolia a young collision zone; In: Collision Tectonics (eds) Coward M P and Ries A C, Geol. Soc. London Spec. Publ. 22 3-36.

Doyuran V, Gülkan P and Koçyiğit A 1989 Seismotectonic evaluation of the Akkuyu nuclear power plant site; Middle East Tech. Univ., Ankara; Unpubl. Report GeologyGeophysics Research Center, 69pp.

Evans G, Morgan P, Evans W E, Evans T R and Woodside J M 1978 Faulting and halokinetics in the north eastern Mediterranean between Cyprus and Turkey; Geology 6 392-396.

Glover C and Robertson A H F 1998 Role of extensional process and uplift in the Plio-Quaternary sedimentary and tectonic evolution of the Aksu-Basin, south west Turkey; J. Geol. Soc. London 155 335-365.

Gokcen S L, Kelling G, Gokcen N and Floyd P A 1988 Sedimantology of a late Cenozoic collisional sequence: the Misis Complex, Adana, South Turkey; Sedim. Geol. 59 205-235.

Hancock P L and Barka A A 1980 Plio-Pleistocene reversal of displacement on the North Anatolian Fault Zone; Nature 286 591-594.

Hooker A T 1981 Interpretation of Seismic Record Sections from the Cilician Basin, Northeast Mediterranean; Unpubl. M.S. thesis, New Mexico State Univ., 83pp.

Hsü K J, Cita M B and Ryan W B F 1973 The origin of the Mediterranean evaporates; In: Init. Reports of Deep-Sea Drilling Project (eds) Ryan W B F, Hsu K J 
and others, 13 U.S. Printing Office, Washington D.C., pp. 1023-1231.

Işler F I, Aksu A E, Hall J, Calon T J and Yaşar D 2005 Neogene development of the Antalya Basin, Eastern Mediterranean: An active forearc basin adjacent to an arc junction; Mar. Geol. 221 299-330.

Jackson J and McKenzie D P 1984 Active tectonics of the Alpine-Himalayan belt between western Turkey and Pakistan; Geophys. J. Roy. Astron. Soc. 77 155-264.

Kahle H-G, Cocard M, Peter Y, Geiger A, Reilinger R, Barka A and Veis G 2000 GPS-derived strain rate field with in the boundary zones of the Eurasian, African and Arabian plates; J. Geophys. Res. 105 23,353-23,370.

Kelling G, Gokcen S L, Floyd P A and Gokcen N S 1987 New data from south Turkey bearing on Neogene tectonics and plate motions in the eastern Mediterranean region; Geology 15 425-429.

Kempler D and Garfunkel Z 1994 Structures and kinematics in the northeastern Mediterranean: A study of an irregular plate boundary; Tectonophys. 234 19-32.

Le Pichon X, Chamot-Rooke N, Lallemant S, Noomen R and Veis G 1995 Geodetic determinations of central Greece with respect to Europe: implications for eastern Mediterranean tectonics; J. Geophys. Res. 100 12,675-12,690.

McClusky S, Balassanian S, Barka A, Demie C, Ergintav S, Georgiev I, Gurkan O, Hamburger M, Hurst K, Kahle H, Kastens K, Kekelidze K, King R, Kotzev V, Lenk O, Mahmoud S, Mishin A, Nadariya M, Ouzounis A, Paradissis D, Peter Y, Prilepin M, Reilinger R, Sanl I, Seeger H, Tealeb A, Toksoz M N and Veis G 2000 Global positioning system constraints on plate kinematics and dynamics in the Eastern Mediterranean and Caucasus; J. Geophys. Res. 105 5695-5719.

Rigassi D 1971 Petroleum geology of Turkey. In: Geology and History of Turkey (ed.) Campbell A S, Petroleum Exploration Soc. of Libya, Tripoli, Libya, pp. $453-482$.

Robertson A H F 1998a Mesozoic-Tertiary tectonic evolution of the easternmost Mediterranean area: integration of marine and land evidence. In: Proc. ODP (eds)
Robertson A H F, Emeis K-C, Richter C and Camerlenghi A, Sci. Results 160 723-782.

Robertson A H F 1998b Tectonic significance of the Eratosthenes Seamount: a continental fragment in the process of collision with a subduction zone in the eastern Mediterranean (Ocean Drilling Program Leg 160); Tectonophys. 298 63-82.

Ryan W B F and Cita M B 1978 The nature and distribution of Messinian erosional surfaces indicators of a several-kilometers deep Mediterranean in the Miocene; Mar. Geol. 27 193-230.

Şengör A M C and Yılmaz Y 1981 Tethyan evolution of Turkey: a plate tectonic approach; Tectonophys. $\mathbf{7 5}$ 181-241.

Şengör A M C, Görür N and Saroğlu F 1985 Strike-slip faulting and related basin formation in zones of tectonic escape: Turkey as a case study; In: Strike-slip Deformation, Basin Formation and Sedimentation (eds) Biddle T R and Christie-Blick N, Soc. Econ. Palaeont. Mineral. Spec. Publ. 37 227-264.

Veen J H, Ten W J M, Zitter T A C, Dumont J F, Mascle $\mathrm{J}$ and Volkonskaia A 2004 Neotectonic evolution of the Anaximander Mountains at the junction of the Hellenic and Cyprus arcs; Tectonophys. 391 35-65.

Vidal N, Klaeschen D, Kopf A, Docherty C, Von Huene R and Krasheninnikov V A 2000 Seismic images at the convergence zone from south of Cyprus to the Syrian coast, eastern Mediterranean; Tectonophys. 329 157-170.

Woodside J M, Mascle J, Zitter T A C, Limonov A F, Ergün M, Volkonskaia A and shipboard scientists of the PRISMED II Expedition 2002 Florence Rise, the western bend of the Cyprus Arc; Mar. Geol. 18 177-194.

Yalçın N M and Görür N 1984 Sedimentological evolution of the Adana Basin; In: Proceedings of the International Symposium on the Geology of the Taurus Belt, Ankara (eds) Tekeli O and Göncüoğlu M C, pp. 165-172.

Yetiş C 1984 New observations on the age of the Ecemiş Fault; In: Geology of the Taurus Belt. Maden Tektik Arama Enstitüsü, Ankara, Turkey (eds) Tekeli $\mathrm{O}$ and Goncuoğlu M C, pp. 159-164. 